\title{
Hydrogeochemical characterization of groundwater of peninsular Indian region using multivariate statistical techniques
}

\author{
T. German Amali Jacintha ${ }^{1} \cdot$ Kishan Singh Rawat $^{1}$ • Anoop Mishra ${ }^{1} \cdot$ \\ Sudhir Kumar Singh ${ }^{2}$
}

Received: 2 February 2016/ Accepted: 2 March 2016/Published online: 31 March 2016

(c) The Author(s) 2016. This article is published with open access at Springerlink.com

\begin{abstract}
Groundwater quality of Chennai, Tamil Nadu (India) has been assessed during different seasons of year 2012. Three physical (pH, EC, and TDS) and four chemical parameters $\left(\mathrm{Ca}^{2+}, \mathrm{Cl}^{-}, \mathrm{TH}, \mathrm{Mg}^{2+}\right.$ and $\left.\mathrm{SO}_{4}{ }^{2-}\right)$ from 18 bore wells were assessed. The results showed that $\mathrm{pH}$ of majority of groundwater samples indicates a slightly basic

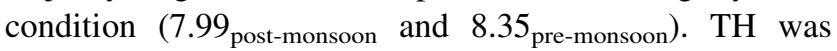
slightly hard [322.11 mg/ $/$ pre-monsoon, $299.37 \mathrm{mg} / \mathrm{l}_{\text {post-monsoon }}$ but lies under World Health Organization (WHO) upper limit]. EC, TDS, $\mathrm{Ca}^{2+}$ and $\mathrm{Mg}^{2+}$ concentrations were under WHO permissible limit during post-monsoon (1503.42 $\mu \mathrm{S} / \mathrm{cm}, 1009.37,66.58$ and $32.42 \mathrm{mg} / \mathrm{l}$ respectively) and pre-monsoon $(1371.58 \mu \mathrm{S} / \mathrm{cm}, 946.84,71.79$ and $34.79 \mathrm{mg} / \mathrm{l}$, respectively). EC shows a good correlation with $\mathrm{SO}_{4}{ }^{2-}\left(R^{2}=0.59_{\text {pre-monsoon }}, 0.77_{\text {post-monsoon }}\right)$ which indicates that $\mathrm{SO}_{4}{ }^{2-}$ plays a major role in $\mathrm{EC}$ of ground water of bore wells. $\mathrm{SO}_{4}{ }^{2-}$ has also showed positive correlations with TDS $\left(R^{2}=0.84_{\text {pre-monsoon }}, 0.95_{\text {post-monsoon }}\right)$ and TH $\left(R^{2}=0.70_{\text {pre-monsoon }}, 0.75_{\text {post-monsoon }}\right)$. The principal component analysis (PCA)/factor analysis (FA) was
\end{abstract}

Kishan Singh Rawat

ksr.kishan@gmail.com

T. German Amali Jacintha

germanamali@gmail.com

Anoop Mishra

daksha112@gmail.com

Sudhir Kumar Singh

sudhirinau@allduniv.ac.in

1 Centre for Remote Sensing and Geo-Informatics, Sathyabama University, Chennai 600119, Tamil Nadu, India

2 K. Banerjee Centre of Atmospheric and Ocean Studies, IIDS, Nehru Science Centre, University of Allahabad, Allahabad 211002, UP, India carried out; Factor 1 explains 59.154 and $69.278 \%$ of the total variance during pre- and post-monsoon, respectively, with a strong positive loading on $\mathrm{Ca}^{2+}, \mathrm{Mg}^{2+}, \mathrm{SO}_{4}{ }^{2-}$, TDS and a negative loading on $\mathrm{pH}$. Factor ${ }_{2}$ accounts for 13.94 and $14.22 \%$ of the total variance during pre- and postmonsoon, respectively, and was characterized by strong positive loading of only $\mathrm{pH}$ and poor/negative loading of $\mathrm{EC}, \mathrm{Ca}^{2+}, \mathrm{Mg}^{2+}, \mathrm{SO}_{4}{ }^{2-}$, TDS and TH during pre- and post-monsoon. We recommend routine monitoring and thorough treatment before consumption. Further, this study has demonstrated the effectiveness of PCA/FA to assess the hydrogeochemical processes governing the groundwater chemistry in the area.

Keywords Multivariate analysis - Correlation coefficient matrix $\cdot$ PCA $\cdot$ Peninsular India

\section{Introduction}

Chennai is a state capital of Tamil Nadu and fourth largest metropolitan city of India. According to Census of India (2011), groundwater from bore wells is major source of drinking water of 4.68 million residents of rural and urban areas and various industries are located around this area. Concern of groundwater quality in urban and rural areas are reported by many researchers (Singh et al. 2012, 2013a, b, 2015; Srivastava et al. 2013; Gupta et al. 2014; Gautam et al. 2015; Tharkur et al. 2015). Generally ground water quality is affected by many factors such as rainfall, hydrologic fluctuation and climate (Balakrishnan 2008; Kumaresan and Riyazuddin 2005; Singh et al. 2009, 2015). Rapid urbanization and fast growing industrial activities, mining activities etc. have resulted in the degradation of ground water quality (Pejman et al. 2009; Kumaresan and 
Riyazuddin 2005; Singh et al. 2013b, 2015; Srivastava et al. 2011; Bharose et al. 2013). The quality of water depends on geology of an area and may vary with depth of water table, seasonal changes, composition of dissolved salts depending upon source of the salt and soil, and subsurface environment etc. (Uphori and Toth 1988; Gautam et al. 2015). Statistical analysis and principal component analysis (PCA) has offered a great tool for the identification of such similarities among the variables or samples (Liu et al. 2003; Singh et al. 2013a, b, 2015, 2016). PCA is more reliable and pure statistical technique, as it is a nonparametric method of classification (Singh et al. 2016). It makes no assumption about the underlying statistical distribution of the data (Kaiser 1960). The objective of the present study is to hydrogeochemical characterization of groundwater using multivariate statistical analysis of bore well water in study area. The good amount of dataset obtained was subjected to the PCA multivariate analysis to evaluate information about seasonal variation in hydro chemical quality of the study area (Dalton and Upchruch 1978).

\section{Study area}

The study area lies between $12^{\circ} 54^{\prime} 0^{\prime \prime}$ and $13^{\circ} 18^{\prime} 0^{\prime \prime}$ latitude and $80^{\circ} 12^{\prime} 0^{\prime \prime}$ and $80^{\circ} 19^{\prime} 0^{\prime \prime}$ of longitude. It is bounded by the Bay of Bengal on the East and on the remaining three sides by land mass. It has approx $26 \mathrm{~km}$ of sea coast which is flat and sandy for about $1.5 \mathrm{~km}$ from the sea shore. The approx elevation along Chennai coast is around $6.7 \mathrm{~m}$ and $60 \mathrm{~m}$ minimum and maximum, respectively, from mean sea level. Two rivers are running through Chennai, the Adyar river to the south and the Koovam river (or Cooum) through the centre. The Buckingham canal runs through the city parallel to coast in eastern side (Fig. 1).

The fixed bore wells of Chennai Water Metro Board/ Central Ground Water Board have a depth of 10-15 m below ground level (Fig. 1b). Ground water in such study area (nearest of sea) is very much affected by the geological formation (Promma et al. 2007; Laluraj and Gopinath 2006), which is red sandy soil, which influences ground water quality in the shallow zone.

The climate of the region is semi-arid sub-tropical type with temperature ranging from 20 to $37^{\circ} \mathrm{C}$. The area receives scanty rainfall with an average of $812 \mathrm{~mm}$ annually. Both the North East (NE) (the actual rainy season occurs in the months of October-December) and South West (SW) monsoon (occurs in the months of JuneSeptember) play a critical role for the availability of rainfall in the study area.

\section{Land use of study area}

Forest cover is very minimal accounting for only about $1.2 \%$ (and $2.9 \%$ plantation of coconut tree etc.,) of the study area $\left(\approx 177.04 \mathrm{~km}^{2}\right)$. A significant portion of the land falls under the category of "non available for cultivation $\left[0.95 \mathrm{~km}^{2} \quad(0.54 \%)\right.$, wasteland, $0.585 \mathrm{~km}^{2}$ $(0.33 \%)$, degraded, $0.39 \mathrm{~km}^{2}(0.22 \%)$, scrub land and $0.938 \mathrm{~km}^{2}(0.53 \%)$, beaches area]" and "fallow lands $\left[1.781 \mathrm{~km}^{2}(1.00 \%)\right.$, open spaces and $0.015 \mathrm{~km}^{2}$ $(0.008 \%)$, grass land]". Tanks [0.64 $\left.\mathrm{km}^{2}(0.36 \%)\right]$, and bore wells are major sources of water supply over study area. The population of Chennai district has grown from 972,288 in 1961 to $1,751,548$ in 2001 and in year 2011 $(4,681,087)$. The growth rate indicates that there has been a significant increase in built up area $\left(159.83 \mathrm{~km}^{2}\right)$ during the 1991-2001 decade with a percentage increase of $90.28 \%$. The economic activities associated with the study area are factories, Auto mobile, tanneries, cement, crackers, and fireworks and printing and allied industries $(\mathrm{Ku}-$ maresan and Riyazuddin 2005).

\section{Soil classification and distribution in study area}

Soils in the area have been classified into deep red loam, black soil and red sandy soil. The majority of the study area is covered by red loam, and red sandy soil. Ferruginous black soils are also seen at places. Black soils are deep to very deep and generally occur in the depressions adjacent to hilly areas of district. Alluvial soils occur along the river courses (CGWB report by Balakrishnan 2008).

\section{Materials and methods}

The data related to groundwater quality were acquired by Chennai Water Metro Board/Central Ground Water Board (CGWB) during pre- and post-monsoon seasons using fixed sampling (because of fixed tube wells) technique. 18 samples were collected during May 2012 and sampling activity was repeated during November 2012. Collected samples were analyzed by CGWB (as per procedure laid down in APHA 1996) in the laboratory to measure the concentration of the quality parameters.

\section{Sulphate $\left(\mathrm{SO}_{4}{ }^{2-}\right)$}

The concentration of sulphate is close to react with human organs if the value exceeds the maximum allowable limit of $400 \mathrm{mg} / \mathrm{l}$ (WHO 1993) and causes a laxative effect on human system with the excess magnesium in groundwater. 


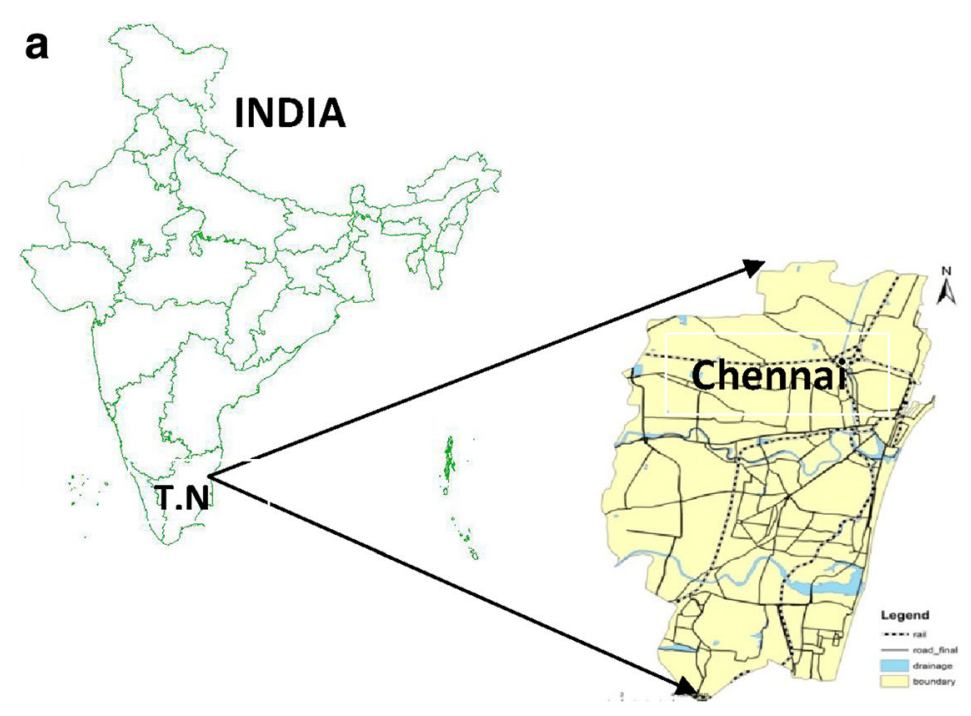

b

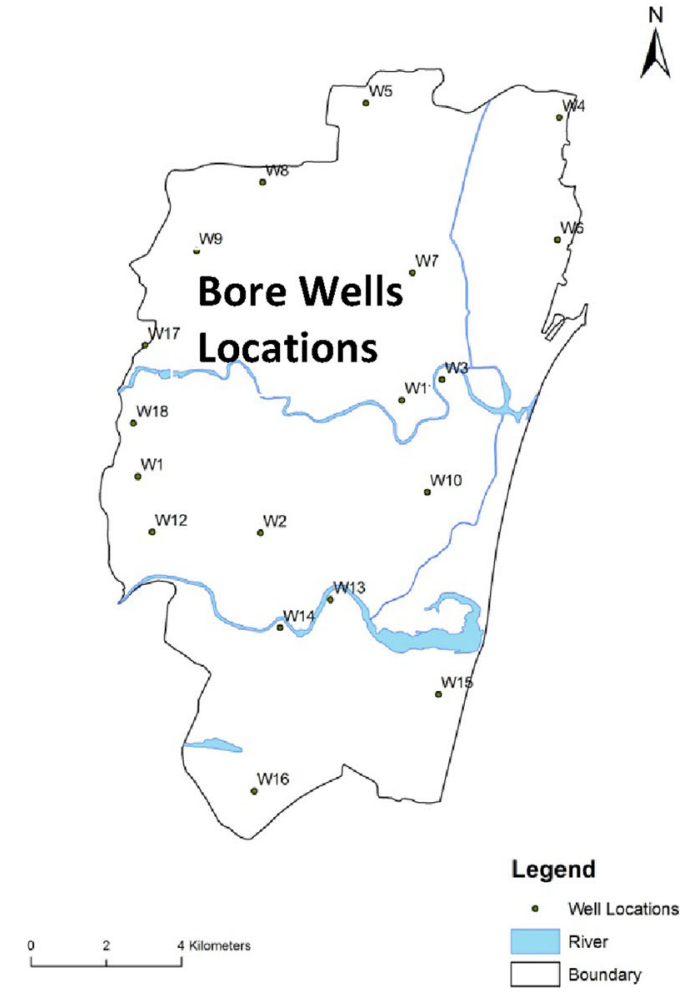

Fig. 1 a Chennai City map, b location of sample wells

\section{Total dissolved solids (TDS)}

Total dissolved solids is an important parameter for assessing groundwater quality, the term is used to describe the inorganic salts and small amounts of organic matter present in solution in water. The principal constituents are usually calcium, magnesium, sodium, and potassium cat ions and carbonate, bicarbonate, chloride, sulphate, and nitrate anions. High TDS levels typically indicate hard water and may lead to scale buildup in pipes, reduced efficiency of water filters, hot water heaters, etc., and aesthetic problems such as a bitter or salty taste (WHO 1993).

(TH)

Total hardness is very important parameter in decreasing the toxic effect of poisonous element and important criterion in determining the suitability of water samples for domestic and industrial purposes as it involved in making the water hard (Rawat et al. 2012, 2013; Laluraj and Gopinath 2006; Gautam et al. 2015; Thakur et al. 2013; Thakur et al. 2015). Hardness of the water results from the presence of divalent metallic cations of which calcium and magnesium are the most abundant in groundwater. Total hardness is determined as $\mathrm{CaCO}_{3}$ in milligrams per liter.
Mainly, TH is caused due to cations of calcium, magnesium, iron, and strontium.TH of the groundwater was calculated using the formula (Todd 1980) given below:

$\mathrm{TH}=2.497 \mathrm{Ca}^{2+}+4.115 \mathrm{Mg}^{2+}$.

High levels of hardness may affect water supply system, excessive soap consumption, calcification of arteries and cause urinary concentrations, diseases of kidney of bladder and stomach disorders.

\section{Statistical analysis}

The statistical analysis is a tool that can be applied to measure variables to identify groundwater pollution (Shrestha and Kazama 2007).

Descriptive statistics of pre- and post-monsoon were processed using Microsoft Office Excel 2007. The statistical parameters like mean, standard error, median, mode, standard deviation $(\sigma)$, sample variance, kurtosis, skewness, range, minimum, maximum and sum were calculated for ground water quality parameters.

\section{Correlation coefficient matrix analysis}

Correlation coefficient matrix of pre- and post-monsoon of parameters were also processed using Microsoft Office

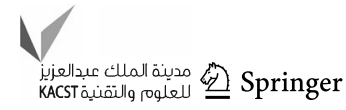


Table 1 Ground water quality parameter at different location of study area during pre-monsoon

\begin{tabular}{|c|c|c|c|c|c|c|c|c|c|}
\hline & Location & $\mathrm{pH}$ & $\mathrm{EC}(\mu \mathrm{S} / \mathrm{cm})$ & $\mathrm{TH}(\mathrm{mg} / \mathrm{l})$ & TDS (mg/l) & $\mathrm{Ca}(\mathrm{mg} / \mathrm{l})$ & $\mathrm{Mg}(\mathrm{mg} / \mathrm{l})$ & $\mathrm{Cl}(\mathrm{mg} / \mathrm{l})$ & $\mathrm{SO}_{4}(\mathrm{mg} / \mathrm{l})$ \\
\hline 1 & Besant Nagar & 8.2 & 1205 & 599.8 & 2400 & 112 & 78 & 560 & 380 \\
\hline 2 & Chindatripet & 8.4 & 860 & 234.6 & 560 & 43 & 31 & 100 & 44 \\
\hline 3 & Kodungaiyur & 8.3 & 1220 & 220.5 & 795 & 80 & 5 & 180 & 70 \\
\hline 4 & Egmore & 8.3 & 1550 & 249.1 & 1010 & 16 & 51 & 210 & 132 \\
\hline 5 & K.K. Nagar & 8.1 & 1160 & 217.9 & 560 & 56 & 19 & 172 & 100 \\
\hline 6 & Kolathur & 8.7 & 970 & 311.3 & 630 & 54 & 43 & 128 & 40 \\
\hline 7 & Kotturpuram & 8.1 & 705 & 128.9 & 460 & 45 & 4 & 100 & 40 \\
\hline 8 & Koyambedu & 8.4 & 2650 & 778.8 & 1350 & 200 & 68 & 350 & 260 \\
\hline 9 & Litte Mount & 8.5 & 1150 & 271.2 & 770 & 56 & 32 & 170 & 84 \\
\hline 10 & Pulianthope & 8.4 & 2000 & 279.9 & 1300 & 48 & 39 & 350 & 312 \\
\hline 11 & Royapettah & 8.3 & 1170 & 169.7 & 760 & 40 & 17 & 110 & 80 \\
\hline 12 & Royapuram & 8.1 & 1100 & 518.3 & 950 & 104 & 63 & 240 & 130 \\
\hline 13 & T. Nagar & 7.9 & 1640 & 330.4 & 1065 & 60 & 44 & 210 & 92 \\
\hline 14 & Thirumangalam & 8.5 & 770 & 262.1 & 500 & 54 & 31 & 100 & 38 \\
\hline 15 & Tondiarpet & 8.4 & 1310 & 289.4 & 850 & 60 & 34 & 230 & 100 \\
\hline 16 & Velachery & 8.4 & 1520 & 358.4 & 860 & 104 & 24 & 170 & 216 \\
\hline 17 & Villivakkam & 8.7 & 1110 & 289.9 & 720 & 52 & 39 & 120 & 20 \\
\hline 18 & Virugampakkam & 8.6 & 2450 & 251.5 & 1590 & 76 & 15 & 220 & 176 \\
\hline
\end{tabular}

Table 2 Ground water quality parameter at different location of study area during post-monsoon

\begin{tabular}{|c|c|c|c|c|c|c|c|c|c|}
\hline & Location & $\mathrm{pH}$ & $\mathrm{EC}(\mu \mathrm{S} / \mathrm{cm})$ & $\mathrm{TH}(\mathrm{mg} / \mathrm{l})$ & TDS (mg/l) & $\mathrm{Ca}(\mathrm{mg} / \mathrm{l})$ & $\mathrm{Mg}(\mathrm{mg} / \mathrm{l})$ & $\mathrm{Cl}(\mathrm{mg} / \mathrm{l})$ & $\mathrm{SO}_{4}(\mathrm{mg} / \mathrm{l})$ \\
\hline 1 & Besant Nagar & 7.6 & 2450 & 407 & 1592 & 48 & 70 & 420 & 256 \\
\hline 2 & Chindatripet & 8.1 & 735 & 169.7 & 478 & 40 & 17 & 112 & 22 \\
\hline 3 & Kodungaiyur & 7.9 & 1420 & 328.6 & 920 & 56 & 46 & 190 & 120 \\
\hline 4 & Egmore & 7.8 & 1100 & 190.2 & 715 & 40 & 22 & 120 & 62 \\
\hline 5 & K.K. Nagar & 7.9 & 1540 & 307.6 & 1000 & 64 & 36 & 190 & 116 \\
\hline 6 & Kolathur & 8.1 & 1005 & 258.9 & 652 & 56 & 29 & 100 & 60 \\
\hline 7 & Kotturpuram & 8.1 & 1135 & 278.4 & 735 & 72 & 24 & 130 & 82 \\
\hline 8 & Koyambedu & 8.1 & 1255 & 268.4 & 815 & 68 & 24 & 12 & 116 \\
\hline 9 & Litte Mount & 8.0 & 1150 & 131 & 718 & 36 & 10 & 100 & 78 \\
\hline 10 & Pulianthope & 8.2 & 3190 & 518.6 & 2074 & 132 & 46 & 490 & 200 \\
\hline 11 & Royapettah & 7.9 & 1270 & 227.9 & 825 & 60 & 19 & 130 & 115 \\
\hline 12 & Royapuram & 7.8 & 1100 & 190.2 & 1398 & 40 & 22 & 120 & 62 \\
\hline 13 & T. Nagar & 8.0 & 1735 & 240.2 & 1128 & 60 & 22 & 200 & 168 \\
\hline 14 & Thirumangalam & 8.1 & 910 & 206.5 & 590 & 58 & 15 & 100 & 60 \\
\hline 15 & Tondiarpet & 8.1 & 1470 & 147.8 & 955 & 46 & 8 & 88 & 298 \\
\hline 16 & Velachery & 8.1 & 3400 & 956.6 & 2210 & 176 & 126 & 780 & 280 \\
\hline 17 & Villivakkam & 8.2 & 1165 & 188.9 & 758 & 28 & 29 & 90 & 68 \\
\hline 18 & Virugampakkam & 8.0 & 1850 & 279.4 & 1170 & 56 & 34 & 180 & 112 \\
\hline
\end{tabular}

Excel 2007. Correlation coefficient is a basic statistical tool to show the degree of dependency of one variable with the other. It is commonly used to measure and establish the relationship between two variables; it also helps to distinguish the relevant hydro chemical facies. By this way, the analysis attempts to establish the nature of the relationship between the water quality parameters (Rawat and Tripathi 2015; Pejman et al. 2009). Correlation analyses were also used to know the trends in water quality parameter during monsoon seasons. The correlation matrix of eight variables 
Table 3 Descriptive statistics of ground water quality parameter at study area during pre-monsoon

\begin{tabular}{llrlllllll}
\hline & Test & $\mathrm{pH}$ & $\mathrm{EC}(\mu \mathrm{S} / \mathrm{cm})$ & $\mathrm{TH}(\mathrm{mg} / \mathrm{l})$ & $\mathrm{TDS}(\mathrm{mg} / \mathrm{l})$ & $\mathrm{Ca}(\mathrm{mg} / \mathrm{l})$ & $\mathrm{Mg}(\mathrm{mg} / \mathrm{l})$ & $\mathrm{Cl}(\mathrm{mg} / \mathrm{l})$ & $\mathrm{SO} 4(\mathrm{mg} / \mathrm{l})$ \\
\hline 1 & Mean & 8.35 & 1371.58 & 322.11 & 946.84 & 71.79 & 34.79 & 204.74 & 133.16 \\
2 & Standard error & 0.05 & 119.7 & 35.74 & 105.85 & 9.25 & 4.61 & 25.98 & 23.25 \\
3 & Median & 8.4 & 1205 & 279.9 & 850 & 56 & 32 & 172 & 100 \\
4 & Mode & 8.4 & 1520 & 358.4 & 560 & 104 & 31 & 100 & 100 \\
5 & Standard deviation & 0.21 & 521.78 & 155.78 & 461.4 & 40.34 & 20.11 & 113.25 & 101.34 \\
6 & Sample variance & 0.04 & 272,255 & 24,265 & 212,892 & 1627 & 404 & 12,824 & 10,270 \\
7 & Kurtosis & 0.02 & 1.27 & 3.44 & 4.7 & 4.89 & -0.04 & 4.62 & 0.54 \\
8 & Skewness & -0.27 & 1.24 & 1.80 & 1.94 & 1.87 & 0.53 & 1.95 \\
9 & Range & 0.8 & 1945 & 649.9 & 1940 & 184 & 74 & 460 \\
10 & Minimum & 7.9 & 705 & 128.9 & 460 & 16 & 4 & 360 \\
11 & Maximum & 8.7 & 2650 & 778.8 & 2400 & 200 & 78 & 560 \\
12 & Sum & 158.7 & 26,060 & 6120.1 & 17,990 & 1364 & 661 & 360 \\
\hline
\end{tabular}

Table 4 Descriptive statistics of ground water quality parameter at study area during post-monsoon

\begin{tabular}{llllllllll}
\hline & Test & $\mathrm{pH}$ & $\mathrm{EC}(\mu \mathrm{S} / \mathrm{cm})$ & $\mathrm{TH}(\mathrm{mg} / \mathrm{l})$ & $\mathrm{TDS}(\mathrm{mg} / \mathrm{l})$ & $\mathrm{Ca}(\mathrm{mg} / \mathrm{l})$ & $\mathrm{Mg}(\mathrm{mg} / \mathrm{l})$ & $\mathrm{Cl}(\mathrm{mg} / \mathrm{l})$ & $\mathrm{SO} /(\mathrm{mg} / \mathrm{l})$ \\
\hline 1 & Mean & 7.99 & 1503.42 & 299.37 & 1009.37 & 66.58 & 32.42 & 192 \\
2 & Standard error & 0.04 & 172.68 & 42.78 & 113.46 & 8.72 & 6.19 & 41.87 & 120.89 \\
3 & Median & 8.00 & 1255 & 258.9 & 825 & 56 & 24 & 120 & 112 \\
4 & Mode & 8.10 & 1100 & 190.2 & - & 40 & 22 & 100 & 22 \\
5 & Standard deviation & 0.15 & 752.72 & 186.49 & 494.56 & 38 & 26.98 & 182.49 & 82.88 \\
6 & Sample variance & 0.02 & 566,580 & 34,776 & 244,588 & 1444 & 727 & 33,301 & 6868 \\
7 & Kurtosis & 0.77 & 1.97 & 8.7 & 1.30 & 3.19 & 8.09 & 5.65 \\
8 & Skewness & -0.91 & 1.59 & 2.69 & 1.36 & 1.89 & 2.63 & 2.34 & 1.04 \\
9 & Range & 0.60 & 2715 & 825.6 & 1765 & 148 & 118 & 768 & 276 \\
10 & Minimum & 7.60 & 685 & 131 & 445 & 28 & 8 & 12 & 22 \\
11 & Maximum & 8.20 & 3400 & 956.60 & 2210 & 176 & 126 & 780 \\
12 & Sum & 151.9 & 28,565 & 5688.1 & 19,178 & 1265 & 616 & 3648 \\
\hline
\end{tabular}

for the pre- and post-monsoon seasons computed in Microsoft Office Excel 2007.

\section{Factor analysis (fa)/principal component analysis (PCA)}

The explanation of hydrogeochemical data of groundwater samples, which have been collected from number of locations, is hampered because it is not easy to visualize and assess the geochemical relationships that may exist using simple histograms and tri-linear diagrams. The most commonly used statistical technique in hydrogeochemistry, FA, a very useful quality data in terms of specific hydrogeochemical process. It is superior to other simple techniques (Cattle 1966). The basic purpose of PCA is to study the hydrogeochemistry of groundwater and explain large amount variance in analytical data by a small number of key factors (Biswal et al. 2004; Dalton and Upchruch 1978; Singh et al. 2009, 2013a, b).

\section{Result from statistical analysis}

\section{Result from descriptive statistics}

The water quality parameters results are given in Table 1 (pre-monsoon) and Table 2 (post-monsoon). Descriptive statistics results of chemical analysis for pre- and postmonsoon seasons are presented in Tables 3 and 4, respectively. The $\mathrm{pH}$ value of groundwater over study area ranges from 7.90 to 8.70 in pre-monsoon and 7.60 to 8.20 during post-monsoon seasons. It may be noted that all well's $\mathrm{pH}$ value falls under WHO (1993) limit except well no. 6, 17 and 18 during pre-monsoon (Fig. 2a). The $\mathrm{pH}$ value of water indicates whether the water is acidic or alkaline. It is controlled by carbon-dioxide, carbonate and bicarbonate equilibrium. The combination of $\mathrm{CO}_{2}$ with water form carbonic acid affects the $\mathrm{pH}$ of the water (Rawat et al. 2012, 2013). If the $\mathrm{pH}$ is not within the prescribed limits, it 

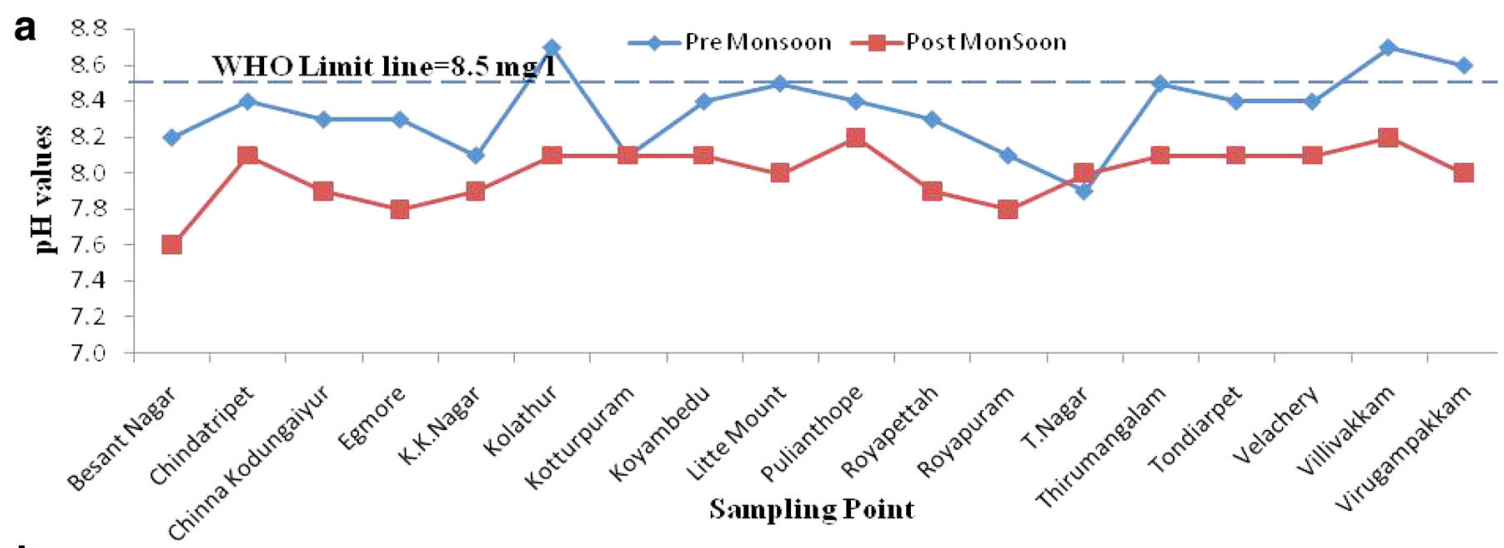

b

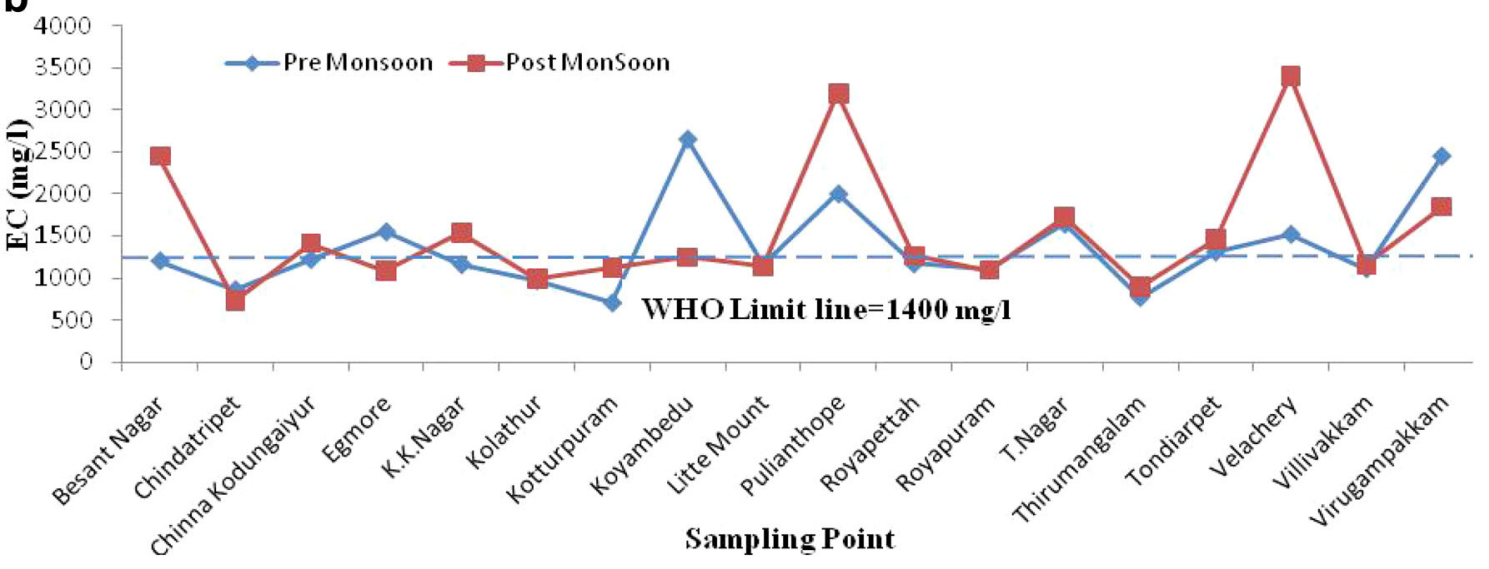

C
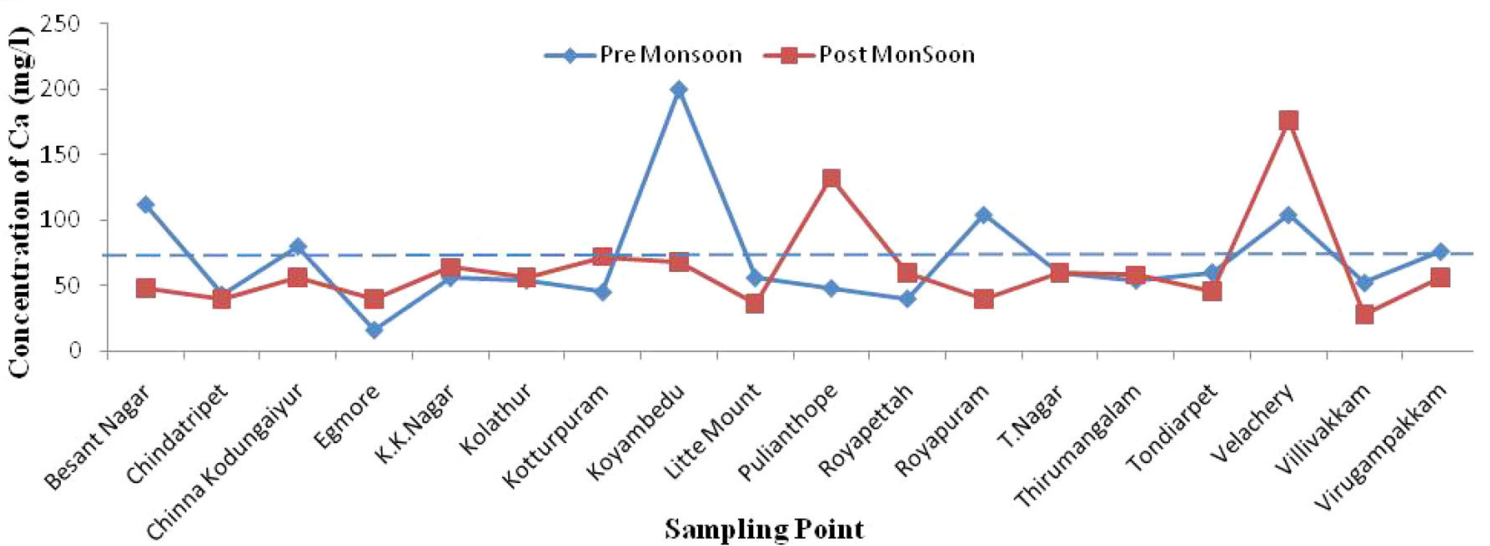

\section{d}

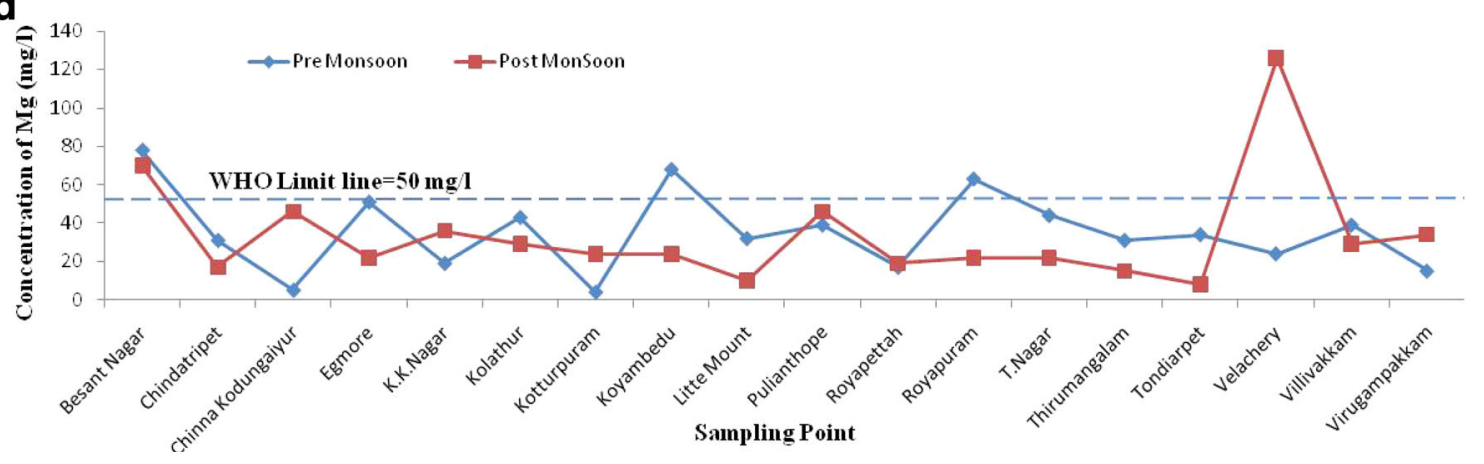


4Fig. 2 Deviation of a pH during pre- and post-monsoon from WHO standard $\mathrm{pH}$ value, b EC during pre- and post-monsoon from WHO standard EC value, c Ca during pre- and post-monsoon from WHO standard $\mathrm{Ca}$ value, $\mathbf{d} \mathrm{Mg}$ during pre- and post-monsoon from WHO standard $\mathrm{Mg}$ value, e $\mathrm{Cl}$ during pre- and post-monsoon from WHO standard $\mathrm{Cl}$ value, f $\mathrm{SO}_{4}$ during pre- and postmonsoon from WHO standard $\mathrm{SO}_{4}$ value, g $\mathrm{TH}$ during pre- and post-monsoon from WHO standard TH value, h TDS during pre- and post-monsoon from WHO standard TDS value

damages mucous membrane present in eyes, nose, mouth, abdomen, anus, etc. Tables 1 and 2 show that pattern of EC in groundwater is not smooth (Fig. 2b). It varies from 705 to $2650 \mu \mathrm{S} / \mathrm{cm}$ in pre-monsoon whereas during post-monsoon season, it ranges from 685 to $3400 \mu \mathrm{S} / \mathrm{cm}$. EC is a measure of salinity hazard. EC in water is due to ionization of dissolved inorganic solids. EC is a measure of water capacity to convey electric current (Rawat et al. 2012, 2013). It is used to estimate the amount of dissolved solids. It increases as the amount of dissolved mineral (ions) increases. It is used as a basic index to select the suitability of water for agricultural purposes. The concentrations of major constituents $\mathrm{Ca}^{2+}$ and $\mathrm{Mg}^{2+}$ show wide variation but their mean values for the pre-monsoon season are 71.79 and $34.79 \mathrm{mg} / \mathrm{l}$, respectively (Table 2; Fig. 3). During post-monsoon season, the average concentration of $\mathrm{Ca}^{2+}$ and $\mathrm{Mg}^{2+}$ lies between $66.58 \mathrm{mg} / \mathrm{l}$ and $32.42 \mathrm{mg} / \mathrm{l}$, respectively (Table 4; Fig. 3). Finally, the $\mathrm{Ca}^{2+}$ and $\mathrm{Mg}^{2+}$, which are in high variability in the ground waters of the study area, ranges from 16 to 200 and 4 to $78 \mathrm{mg} / \mathrm{l}$, respectively during the pre-monsoon while 28 to 176 and 8 to $126 \mathrm{mg} / \mathrm{l}$, respectively in post-monsoon (Tables 2, 3; Fig. 2c, d). $\mathrm{Ca}^{2+}$ occurs in water naturally and it cannot be found alone in nature (Rawat and Tripathi 2015). $\mathrm{Mg}^{2+}$ is the most abundant elements in the natural surface and groundwater. Magnesium is washed from rocks and subsequently ends up in water. Magnesium has many different purposes and consequently may end up in water in many different ways. Chemical industries add magnesium to plastics and other materials as a fire protection measure or as filler (Naik et al. 2007). Similarly $\mathrm{Cl}^{-}$and $\mathrm{SO}_{4}{ }^{2-}$ ranges from 100 to 560 and 20 to $380 \mathrm{mg} / \mathrm{l}$ during pre-monsoon, respectively whereas during post-monsoon they vary from 12 to 780 and 22 to $298 \mathrm{mg} / \mathrm{l}$ respectively. The distribution of $\mathrm{Cl}^{-}$and $\mathrm{SO}_{4}{ }^{2-}$ in ground water of study area is shown in Fig. 2e, f for pre- and post-monsoon. High concentration of $\mathrm{Cl}^{-}$may be injurious to some people suffering from diseases of the heart and kidney, taste, indigestion, corrosion and palatability are affected (Rawat and Tripathi 2015). Figure 2f, shows good variability in distribution pattern of $\mathrm{SO}_{4}{ }^{2-}$ but under the WHO (1993) limit. Hardness of water is primarily due to the result of long-term interaction of water and the geological formations (Hem 1989). The TH concentration of the groundwater in the study area ranges from 128.90 to $778.80 \mathrm{mg} / \mathrm{l}$ during pre-monsoon period and from 131 to $956.60 \mathrm{mg} / \mathrm{l}$ during post-monsoon period. The permissible limit of TH in drinking water is $600 \mathrm{mg} / \mathrm{l}$ (WHO 1993). Results show that all well are under the permissible limit (Fig. $2 \mathrm{~g}$ ) except well no. 8 (during premonsoon) and 16 (during post-monsoon). TDS of all samples values ranges from minimum 460 to $2400 \mathrm{mg} / \mathrm{l}$ during pre-monsoon period. It is reported that all well are under the permissible limit of TDS except four well (well no. 1, 8, 10 and 18; Fig. 2h) and from 445 to $2210 \mathrm{mg} / \mathrm{l}$ during post-monsoon season (and well no. 1, 10, 12, 16 and 18 are exceed the WHO limit; Fig. 2h).

The mean and standard deviations $(\sigma)$ were used to compare the deviation of water quality parameters from WHO standards (WHO 1993). Whenever mean exceeds the permissible limit fixed by WHO, it is concluded that those particular places are all contaminated with respect to the water quality parameters. From Table 5 and 6 (Fig. 3), mean value of $\mathrm{pH}$ [pre 8.35 or $8.35 \times 100$ and post 7.99 or $7.99 \times 100$ (multiplied by 100 for graphical representation (Fig. 3) as other parameter were above 100)] and TH (pre 322.11 and post 299.37) for study area under permissible limit $(8.5$ or $8.5 \times 100$ for $\mathrm{pH}$ and $600 \mathrm{mg} / \mathrm{l}$ for $\mathrm{TH})$ of WHO (1993), $\mathrm{Ca}^{2+}$ and $\mathrm{Mg}^{2+}$ are also under the prescribed permissible limit as 75 and $50 \mathrm{mg} / \mathrm{l}$ during pre- and postmonsoon. It may be noted that mean value of each parameters are under the WHO permissible limit except limit of EC during post-monsoon (Fig. 3). Elevated concentration of water quality parameters in drinking water have been identified in groundwater of 18 bore wells in Chennai district of Tamil Nadu. These bore wells namely: Besant Nagar, Chindatripet, Kodungaiyur, Egmore, K.K. Nagar, Kolathur, Kotturpuram, Koyambedu, Litte Mount, Pulianthope, Royapettah, Royapuram, T. Nagar, Thirumangalam, Tondiarpet, Velachery, Villivakkam, and Virugampakkam were reported high concentration of analyzed parameters.

\section{Result from correlation coefficient matrix}

Correlation matrix of various variables are presented in the Table 3 and shown in Fig. 4. Each table shows the degree of a linear association between two of the parameters (Rawat and Tripathi 2015), as measured by the simple correlation coefficient $(r)$. The correlation among parameters in the pre- and post-monsoon seasons has shown approximately, an anomalous trend. Strong to good correlations among the various water quality parameters has been observed. Strong correlation of TDS and TH with $\mathrm{Ca}^{2+}, \mathrm{Mg}^{2+}$ and $\mathrm{SO}_{4}{ }^{2-}$ indicates that all of them have originated from the same source. It shows that TDS and TH are highly contributed by $\mathrm{Ca}^{2+}, \mathrm{Mg}^{2+}, \mathrm{Cl}^{-}$, and $\mathrm{SO}_{4}{ }^{2-}$ during pre-monsoon monitoring period. From Table $6 \mathrm{Cl}^{-}$ 


\section{e}
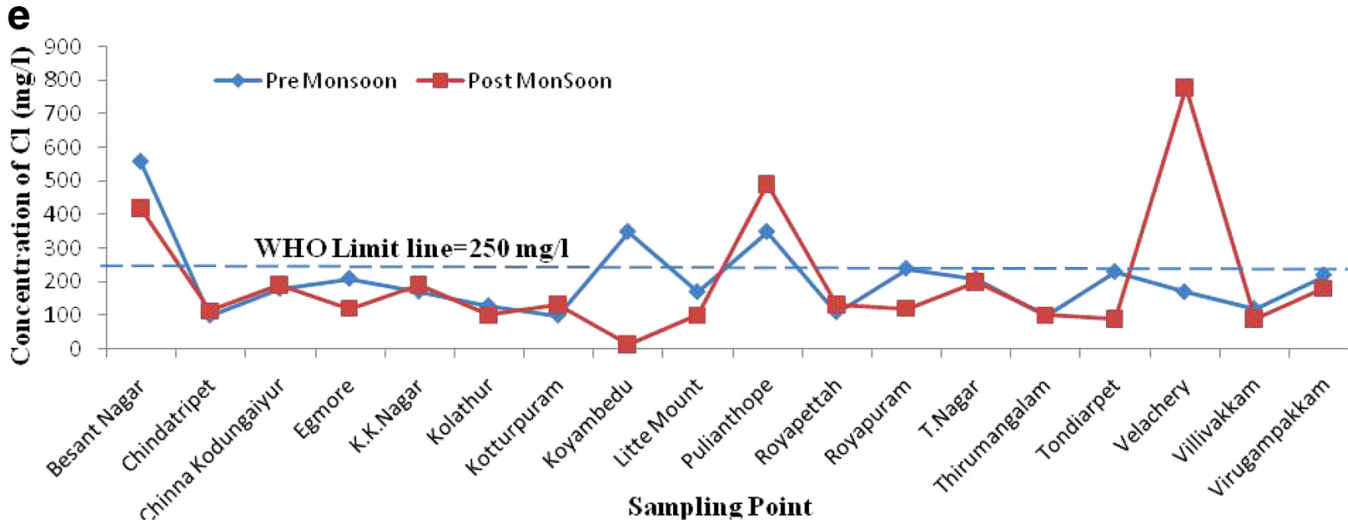

f
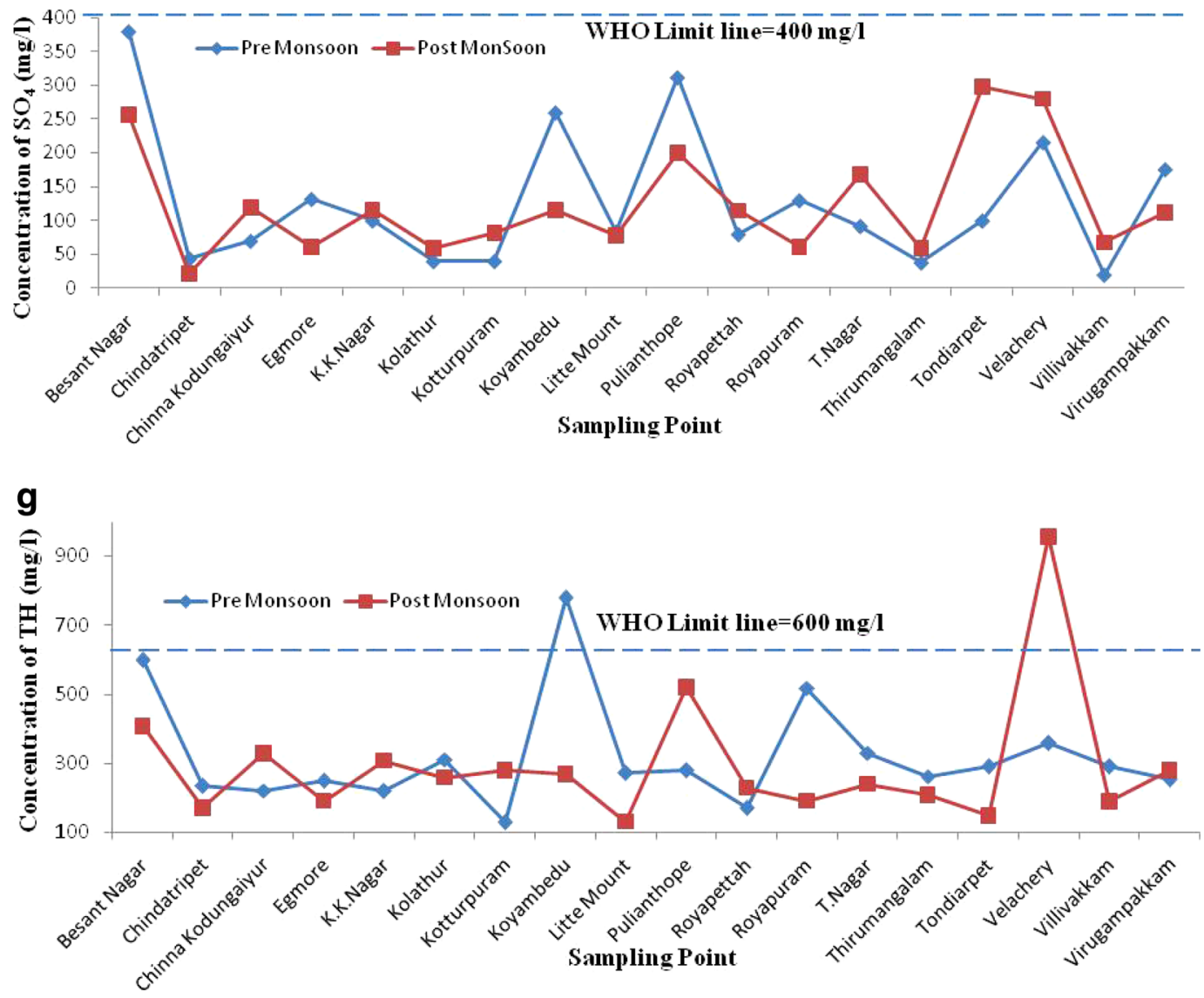

h

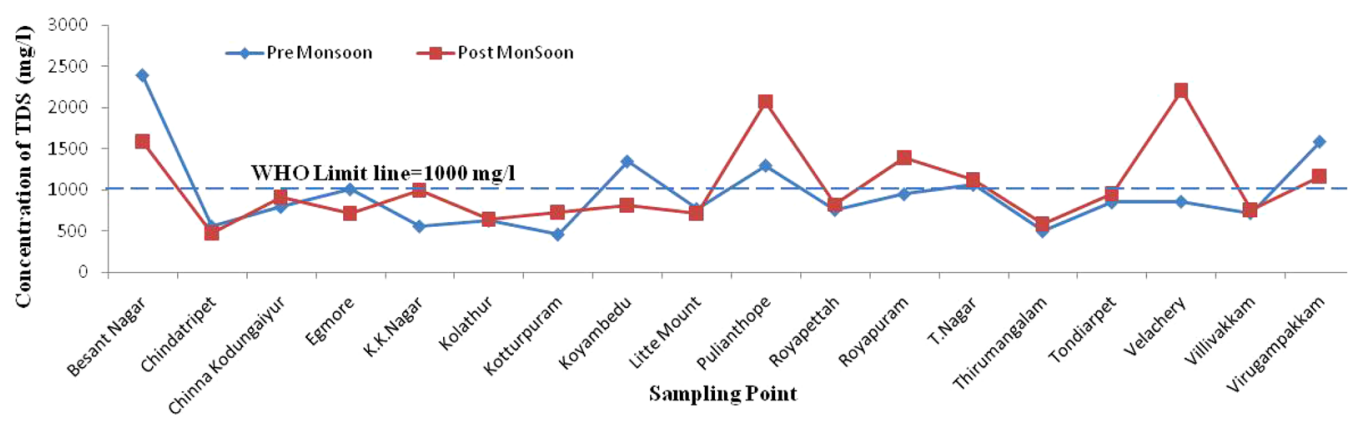

Fig. 2 continued 
Fig. 3 Average concentration of water quality parameters during pre- and post-monsoon season

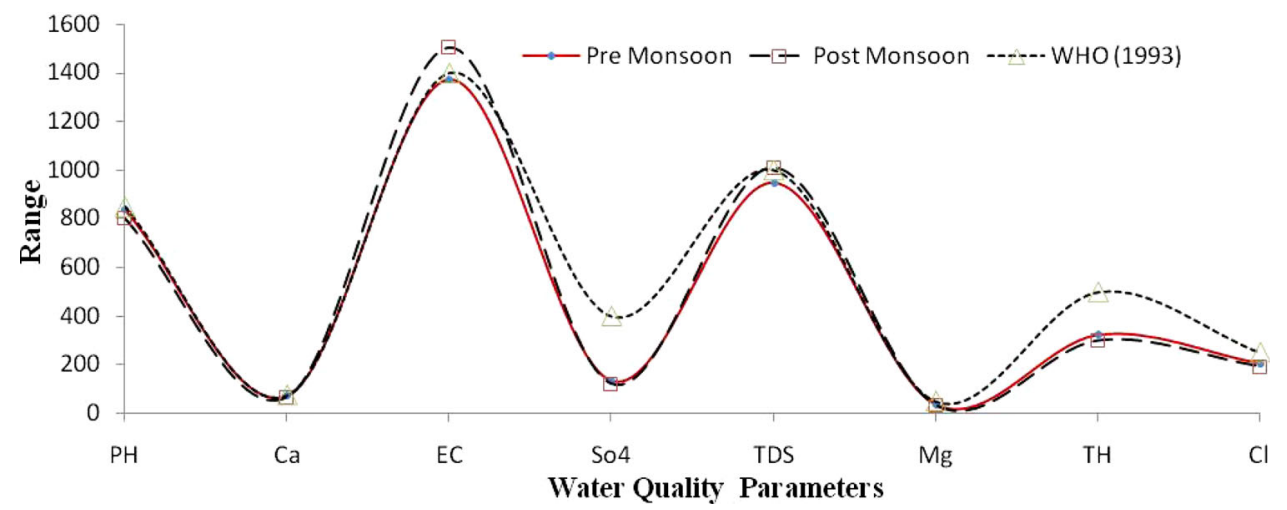

does not play any role in the formation of TDS and TH (due to low $r=0.05_{\mathrm{Cl}-\mathrm{TDS}}, 0.07_{\mathrm{Cl}-\mathrm{TH}}$ ). Table 3 also shows a moderate to poor degree of correlation of $\mathrm{pH}$ with $\mathrm{Ca}^{2+}$ and $\mathrm{Cl}^{-}$during both monsoon periods. However, $\mathrm{pH}$ was found to be significantly correlated (Table 6; Fig. 4) with $\mathrm{Mg}^{2+}, \mathrm{SO}_{4}{ }^{2-}$, TDS and $\mathrm{TH}$ during post-monsoon season indicating the presence of + and - ions (which is evidence of strong $\mathrm{pH}$ formation) from $\mathrm{Mg}^{2+}$ and $\mathrm{SO}_{4}{ }^{2-}$ during post-monsoon. EC is highly correlated with $\mathrm{SO}_{4}{ }^{2-}$ during both monsoon period. $\mathrm{EC}$ and $\mathrm{Ca}^{2+}$ shows moderate correlation $\left(r_{\text {pre }}=0.54\right.$ and $\left.r_{\text {post }}=0.58\right)$, conforming that conductivity increases as the concentration of dissolved calcium ions increases. TH exhibits strong and good correlations with $\mathrm{Ca}^{2+}\left(r_{\text {pre }}=0.88\right.$ and $\left.r_{\text {post }}=0.52\right)$ and $\mathrm{Mg}^{2+}\left(r_{\text {pre }}=0.81\right.$ and $\left.r_{\text {post }}=0.91\right)$ in both the seasons indicating that hardness of groundwater in the study area is mainly due to the salts like $\mathrm{CaCO}_{3}$ and $\mathrm{MgCO}_{3}$.

\section{Multivariate statistical analysis}

The PCA results along with factor loading values and percentage of variance for 18 bore wells are presented in Table 7. An Eigen value gives a measure of the significance of the factor (Kaiser 1960; Dalton and Upchruch 1978; Cattle 1966), the factor with highest Eigen values are the most significant. Eigen values of 1.0 or greater are considered significant. Factor loading is classified as strong, moderate and weak corresponding to absolute loading values of $>0.75,0.75-0.50$ and $0.50-0.30$, respectively (Liu et al. 2003) Two factors or PCs explained 73.10 and $83.50 \%$ of the total variances for pre- and postmonsoon, respectively, which was adequate to give a good initiative of the data structure.

\section{Pre-monsoon}

During pre-monsoon season (Table 7; Fig. 5a), variance of Factor $_{1}$ during pre-monsoon season is $59.15 \%$. It is reported that Eigen value with 4.732 and variance of
$59.15 \%$ has high loadings on $\mathrm{Ca}^{2+}, \mathrm{Mg}^{2+}, \mathrm{SO}_{4}{ }^{2-}, \mathrm{Cl}^{-}$, TDS, and TH, moderate loadings on EC and low loadings on $\mathrm{pH}$.

1. High loading: it suggests that the quality of groundwater is mainly controlled by high loading parameters. The high $\mathrm{SO}_{4}{ }^{2-}$ is related to the long-history of evaporation process, the high value of $\mathrm{Mg}^{2+}$ suggests pollution from application of magnesium sulphate fertilizers (anthropogenic pollution factor) to agricultural lands (Rawat and Tripathi 2015; Singh et al. 2015) and high loading on TS and TDS accounts for low mixing of overlying soft soil after percolation due to monsoon runoff pollution. Therefore, two facts are responsible for high loading on these elements, lowering of groundwater table (during pre-monsoon) and anthropogenic pollution due to direct discharge of sewage into water body without treatment (Gautam et al. 2013). During the summer season, without recharge, lowering of groundwater table occurs since high concentration $\mathrm{Ca}^{2+}, \mathrm{Cl}^{-}$, and TDS were recorded. The other contributing process is suggested as anthropogenic pollution due to presence of $\mathrm{Mg}^{2+}$ and $\mathrm{SO}_{4}{ }^{2-}$ (leach of magnesium sulphate fertilizers, Hounslow 1995; Hem 1989; Singh et al. 2015).

2. Moderate loading: EC

3. Low loading: the negative loading of $\mathrm{pH}$ on Factor ${ }_{1}$ confirms that the concentration of $\mathrm{pH}$ in the groundwater does not contribute significantly to $\mathrm{Ca}^{2+}, \mathrm{Mg}^{2+}$, $\mathrm{SO}_{4}{ }^{2-}, \mathrm{Cl}^{-}$, TDS, and $\mathrm{TH}$ values during pre-monsoon

Factor $_{2}$ having Eigen value with 1.115 and $13.94 \%$ of the variance, has high loadings of $\mathrm{pH}$ and moderate loadings on $\mathrm{EC}$ and low loadings on $\mathrm{Ca}^{2+}, \mathrm{Mg}^{2+}, \mathrm{SO}_{4}{ }^{2-}, \mathrm{Cl}^{-}$, TDS, and TH.

1. High loading: if $\mathrm{pH}$ high (high loadings of $\mathrm{pH}$ in Factor $_{2}$ ) positive loading which indicate ground water are mostly polluted by discharge of waste water as a regular source in the study area. Owing to degradation of organic material $\mathrm{pH}$ Increases due to formation of 
Table 5 Correlation matrix for different ground water quality parameter at study area during pre-monsoon

\begin{tabular}{|c|c|c|c|c|c|c|c|c|}
\hline & $\mathrm{pH}$ & $\mathrm{EC}$ & $\mathrm{Ca}$ & $\mathrm{Mg}$ & $\mathrm{SO}_{4}$ & $\mathrm{Cl}$ & TDS & $\mathrm{TH}$ \\
\hline $\mathrm{pH}$ & 1 & & & & & & & \\
\hline $\mathrm{EC}$ & 0.10 & 1 & & & & & & \\
\hline $\mathrm{Ca}$ & -0.03 & 0.54 & 1 & & & & & \\
\hline $\mathrm{Mg}$ & -0.07 & 0.23 & 0.44 & 1 & & & & \\
\hline $\mathrm{SO}_{4}$ & -0.12 & 0.59 & 0.56 & 0.50 & 1 & & & \\
\hline $\mathrm{Cl}$ & -0.21 & 0.46 & 0.52 & 0.69 & 0.88 & 1 & & \\
\hline TDS & -0.09 & 0.55 & 0.45 & 0.59 & 0.84 & 0.92 & 1 & \\
\hline $\mathrm{TH}$ & -0.06 & 0.47 & 0.88 & 0.81 & 0.63 & 0.70 & 0.60 & 1 \\
\hline
\end{tabular}

The bold values represent the existing good correlation between the variables

Table 6 Correlation matrix for different ground water quality parameter at study area during post-monsoon

\begin{tabular}{|c|c|c|c|c|c|c|c|c|}
\hline & $\mathrm{pH}$ & $\mathrm{EC}$ & $\mathrm{Ca}$ & $\mathrm{Mg}$ & $\mathrm{SO}_{4}$ & $\mathrm{Cl}$ & TDS & $\mathrm{TH}$ \\
\hline $\mathrm{pH}$ & 1 & & & & & & & \\
\hline EC & 0.64 & 1 & & & & & & \\
\hline $\mathrm{Ca}$ & 0.36 & 0.58 & 1 & & & & & \\
\hline $\mathrm{Mg}$ & 0.72 & 0.92 & 0.66 & 1 & & & & \\
\hline $\mathrm{SO}_{4}$ & 0.57 & 0.77 & 0.73 & 0.89 & 1 & & & \\
\hline $\mathrm{Cl}$ & 0.23 & -0.08 & -0.03 & -0.02 & -0.05 & 1 & & \\
\hline TDS & 0.62 & 0.81 & 0.79 & 0.92 & 0.95 & 0.05 & 1 & \\
\hline $\mathrm{TH}$ & 0.89 & 0.92 & 0.52 & 0.91 & 0.75 & 0.07 & $\mathbf{0 . 8 0}$ & 1 \\
\hline
\end{tabular}

The bold values represent the existing good correlation between the variables

acids, therefore this factor termed as degradation factor.

2. Moderate loading: EC represents solubility of minerals.

3. Low loading: presence of $\mathrm{Ca}^{2+}, \mathrm{Mg}^{2+}, \mathrm{SO}_{4}{ }^{2-}, \mathrm{Cl}^{-}$, TDS, and TH indicates mild pollution.

\section{Post-monsoon}

During post-monsoon season (Table 7; Fig. 5b), the Factor $_{1}$ is very strongly correlated with EC, TH and TDS, and strongly correlated with $\mathrm{Cl}^{-}$and $\mathrm{Mg}^{2+}$. It is moderately correlated with $\mathrm{Ca}^{2+}$ and $\mathrm{Ca}^{2+}, \mathrm{Mg}^{2+}, \mathrm{SO}_{4}{ }^{2-}, \mathrm{Cl}^{-}$, TDS which explain $69.28 \%$ of variability in the dataset. This may be due to recharge effect of rain water since $\mathrm{Ca}^{2+}$ and $\mathrm{SO}_{4}{ }^{2-}$ show moderately positive correlation when compared with pre-monsoon seasons.

Factor $_{2}$ accounts for $14.22 \%$ of variability and include strong positive loading of EC and low loading of $\mathrm{pH}$, by the change in $\mathrm{pH}$ of the water, most likely due to constant water inflow. It is due to sudden influx of fresh rain water in the study area.
In the both the season, Factor ${ }_{2}$ of $\mathrm{pH}$ was exhibiting more (in this study each water quality parameter with a strong Eigen value $(>75 \%)$ was considered to be significant parameters equally contributing and strong factor loadings in water quality variations for two seasons) strong positive association.

A screen plot (Fig. 5a, b) shows the eigen values sorted from large to small as a function of the principal component number. After the 2 PC (Fig. 5a, b), starting the elbow the downward curve. Other components weight, their eigen values and variances are summarized in Table 7 . Loading of varimax rotated matrix for two factor model are shown in Table 7. Evidently, the first factor is usually more correlated with the variables than the second factor (Kaiser 1960; Dalton and Upchruch 1978; Cattle 1966; Singh et al. $2013 \mathrm{~b}, 2015)$. This is to be expected because these factors are extracted successively, each one accounting for as much of the remaining variance as possible.

According to Liu et al. (2003), total variance (Table 7) has strong positive loadings on $\mathrm{Cl}^{-}, \mathrm{Ca}^{2+}, \mathrm{Mg}^{2+} \mathrm{TH}$ and TDS, weak loading on EC during pre-monsoon season. Whereas, strong positive loading on EC and weak loading on $\mathrm{Mg}^{2+}$, $\mathrm{Ca}^{2+}, \mathrm{Cl}^{-}, \mathrm{SO}_{4}{ }^{2-}$, $\mathrm{TH}$ and TDS during post-monsoon season 
Fig. 4 Radar charts of correlation coefficient between groundwater quality parameters

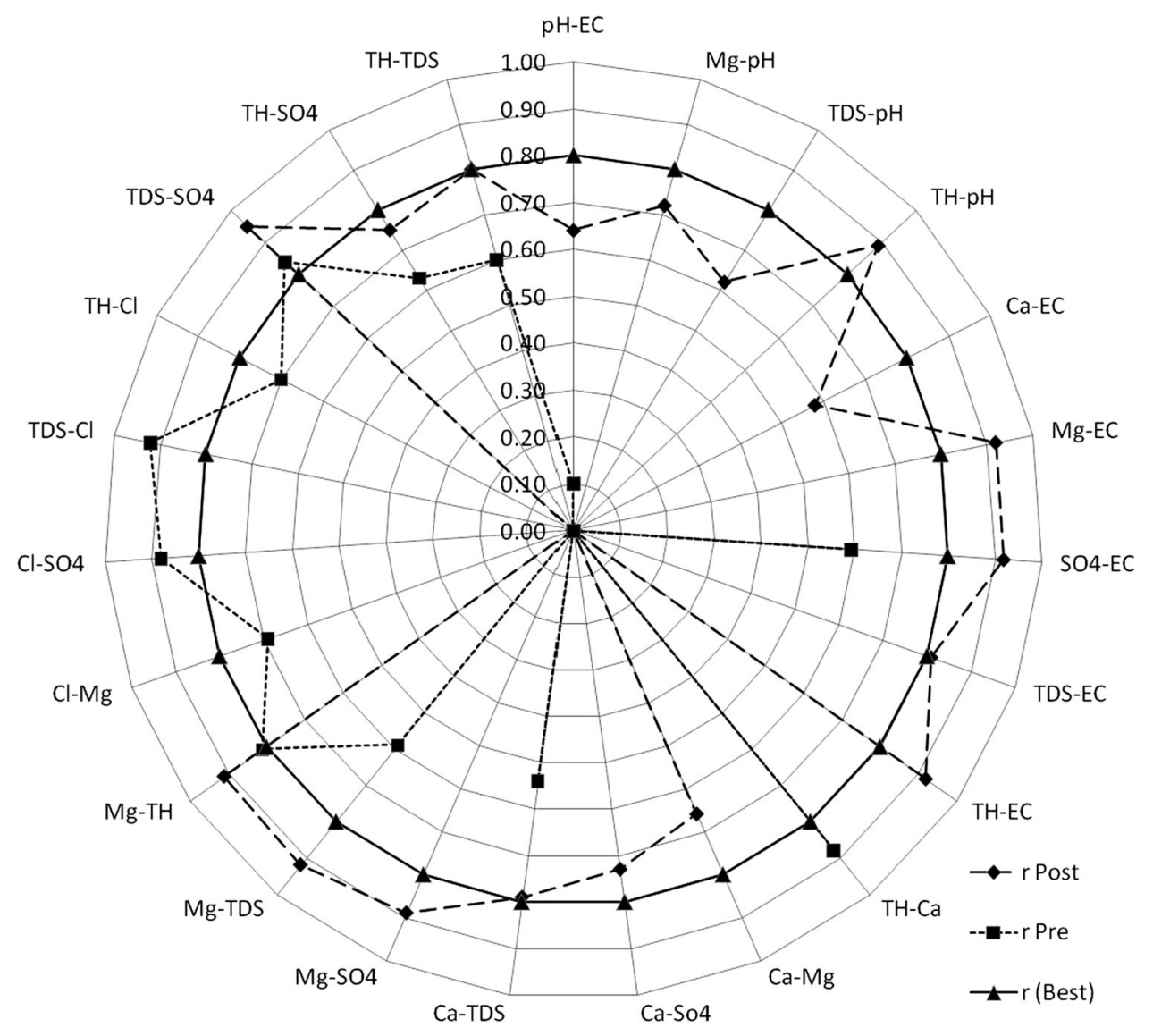

Table 7 The factor loading and the explained variance of water quality parameters in two seasons

\begin{tabular}{|c|c|c|c|c|}
\hline & \multicolumn{2}{|c|}{ Pre-monsoon } & \multicolumn{2}{|c|}{ Post-monsoon } \\
\hline & Factor $_{1}$ & Factor $_{2}$ & Factor $_{1}$ & Factor $_{2}$ \\
\hline $\mathrm{pH}$ & -0.1200 & 0.8830 & 0.03 & 0.914 \\
\hline $\mathrm{EC}$ & 0.6450 & 0.4270 & 0.951 & $-6.86 \mathrm{E}-02$ \\
\hline $\mathrm{Ca}$ & 0.7560 & 0.2510 & 0.772 & 0.418 \\
\hline $\mathrm{Mg}$ & 0.7500 & -0.1480 & 0.915 & $-7.81 \mathrm{E}-02$ \\
\hline $\mathrm{SO}_{4}$ & 0.8810 & -0.0422 & 0.739 & -0.247 \\
\hline $\mathrm{Cl}$ & 0.9180 & -0.2240 & 0.975 & $-3.74 \mathrm{E}-02$ \\
\hline TDS & 0.8730 & -0.0914 & 0.913 & -0.162 \\
\hline $\mathrm{TH}$ & 0.8860 & 0.0843 & 0.936 & -0.167 \\
\hline Total & 4.732 & 1.115 & 5.542 & 1.138 \\
\hline Variance \% & 59.154 & 13.937 & 69.278 & 14.224 \\
\hline Cumulative \% & 59.154 & 73.091 & 69.278 & 83.502 \\
\hline
\end{tabular}

are the major solutes in groundwater. EC is positively correlated with the concentration of ions, which can thus be indirectly calculated from EC. Therefore, EC can be regarded as a water salinization index. The association of $\mathrm{EC}, \mathrm{Cl}^{-}$, $\mathrm{Mg}^{2+}, \mathrm{SO}_{4}{ }^{2-}$, $\mathrm{TH}$ and TDS reflects the influence of sea water intrusion on pollution of groundwater and can thus be termed "the sea water salinization factor".

\section{Conclusion}

A high degree of correlation (positive) of total hardness with $\mathrm{Mg}^{2+}$ indicates that hardness was mainly contributed by salts of $\mathrm{Mg}^{2+}$. The present study reveals that water quality deterioration is due to various reasons. Better water quality was found in the post-monsoon season than that of 

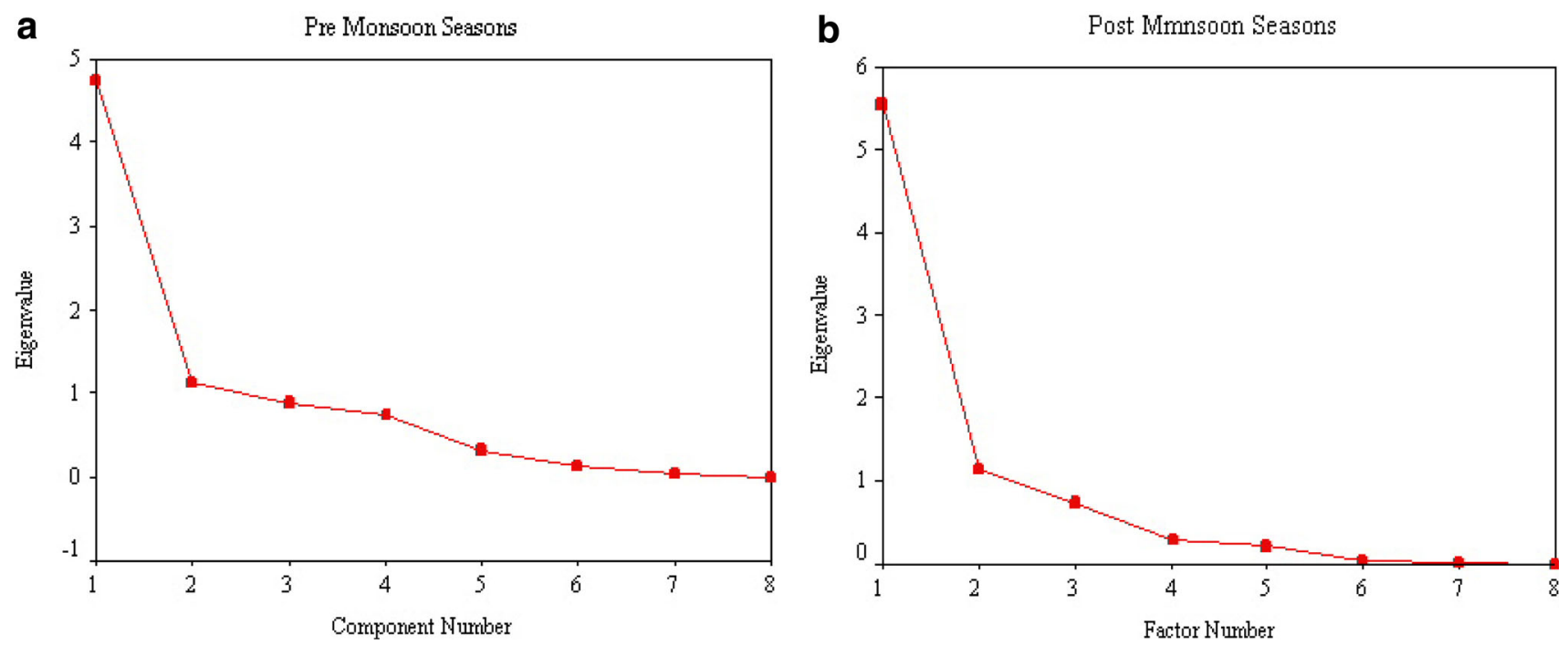

Fig. 5 Screen plot shows (component number/factor number) the Eigen values during pre- and post-monsoon season

pre-monsoon season due to water recharge from rains. Extent of pollution occurred due to urbanization and anthropogenic activities. The hydrogeochemical variance of the water samples appears to characterize the water rock interaction processes, responsible for the high loadings in $\mathrm{SO}_{4}{ }^{2-}, \mathrm{Cl}^{-}, \mathrm{Mg}^{2+}$, TDS and TH. Generally the ground water falls in the slight hard to hard category. TDS is found higher in post-monsoon than pre-monsoon, this is due to the effect of leaching/percolation due to monsoon runoff pollution from buildup area, which leads to less dilution process during recharging of groundwater. An increase in the concentration of $\mathrm{Ca}^{2+}, \mathrm{Mg}^{2+}$ and $\mathrm{Cl}^{-}$are the main cause of the salinization in study area. The overall hydrochemistry reflects rock weathering with inputs from anthropogenic impacts due to the fast urbanization (or high buildup area existing in study area). Hydrogeochemistry reveals that the order of cation abundance is $\mathrm{Ca}^{2+}>\mathrm{Mg}^{2+}$ except in some groundwater samples where $\mathrm{Mg}$ replaces $\mathrm{Ca}^{2+}$, and in anionic chemistry, the order is $\mathrm{Cl}^{-}>\mathrm{SO}_{4}{ }^{2-}$. It is evident from the higher values of physico-chemical results especially $\mathrm{pH}, \mathrm{EC}$, hardness, and TDS, that most of the wells in the present investigation are contaminated by sewage (because of high buildup area existing in study area) and industrial effluents. The quality of groundwater can be improved in affected areas by implementing various groundwater management schemes like identifying artificial recharge sites and construction of percolation ponds, rainwater harvesting techniques, etc. Community based public participation program is essential to improve the quality of groundwater, conservation and groundwater literacy program from school level can also play a major role to ensure pollution-free water.

It is evident that PCA can be used as one of the predominant techniques to assess groundwater quality. Use of integrated techniques is recommended as future scope. This can be helpful to overcome the limitations attached to each individual technique.

Acknowledgments The authors are grateful to K. Santhanam [Former Joint Director (Geology), Water Resources Division, P.W.D, Chennai] for providing water quality datasets of 2012 and thank Dr. Anil Kumar Mishra (Principal Scientists, Water Technology Centre, IARI, New Delhi) for his critical input and suggestions on the manuscript.

Open Access This article is distributed under the terms of the Creative Commons Attribution 4.0 International License (http:// creativecommons.org/licenses/by/4.0/), which permits unrestricted use, distribution, and reproduction in any medium, provided you give appropriate credit to the original author(s) and the source, provide a link to the Creative Commons license, and indicate if changes were made.

\section{References}

APHA (1996) Standard methods for examination of water and waste water, 19th edn. Washington DC

Balakrishnan T (2008) Technical report series. District groundwater brochure Chennai District Tamil Nadu, Government of India Ministry of Water Resources Central Ground Water Board South Eastern Coastal Region, Chennai, November 2008

Bharose R, Singh SK, Srivastava PK (2013) Heavy metals pollution in soil-water-vegetation continuum irrigated with ground water and untreated sewage. Bull Environ Sci Res 2:1-8

Biswal A, Singh AK, Tadi SG, Chandrasekharan H (2004) Assessment of ground water quality at IARI farm, New Delhi. J Water Manag 12:40-46

Cattle RD (1966) The scree test for the number of factors. Multivar Behav Res 1:245-276

Dalton MG, Upchruch SB (1978) Interpretation of hydro chemical fancies by factor analysis. Groundwater 16:228-233

Gautam SK, Sharma D, Tripathi JK, Ahirwar S (2013) A study of the effectiveness of sewage treatment plants in Delhi region. Appl Water Sci 3:57-65 
Gautam SK, Maharana C, Sharma D, Singh AK, Tripathi JK, Singh SK (2015) Evaluation of groundwater quality in the Chotanagpur plateau region of the Subarnarekha river basin, Jharkhand State, India. Sustain Water Qual Ecol 6:57-74. doi:10.1016/j.swaqe. 2015.06.001

Gupta LN, Avtar R, Kumar P, Gupta GS, Verma RL, Sahu N, Sil S, Jayaraman A, Roychowdhury K, Mutisya E et al (2014) A multivariate approach for water quality assessment of River Mandakini in Chitrakoot, India. J Water Resour Hydraul Eng 3:22-29

Hem JD (1989) Study and interpretation of the chemical characteristics of natural water, 3rd edn, U.S geological survey watersupply paper 2254. United States Government Printing Office

Hounslow AW (1995) Water quality data analysis and interpretation. Lewis Publishers, Oklahoma State University, Stillwater, p 39

Kaiser HF (1960) The application of electronic computers to factor analysis. Edu Psychol Meas 20:141-151

Kumaresan M, Riyazuddin P (2005) Major ion chemistry of environmental samples around sub-urban of Chennai city. Curr Sci 91:1668-1677

Laluraj CM, Gopinath G (2006) Assessment on seasonal variation of groundwater quality of pheratic aquifer-a river basin system. Environ Monit Assess 117:45-57

Liu CWKH, Kuo YM (2003) Application of factor analysis in the assessment of ground water quality in a back foot disease area in Taiwan. Sci Total Environ 313(1-3):77-89

Naik PK, Dehury BN, Tiwari AN (2007) Groundwater pollution around an industrial area in the coastal stretch of Maharashtra state, India. Environ Monit Assess 132:207-233

Pejman AH, Nabi Bidhendi GR, Karbassi AR, Mehrdadi N, Esmaeil Bidhendi M (2009) Evaluation of spatial and seasonal variations in surface water quality using multivariate statistical techniques. J Environ Sci Tech 6(3):467-476

Promma K, Zheng C, Asnachinda P (2007) Groundwater and surfacewater interactions in a confined alluvial aquifer between two rivers: Effects of groundwater flow dynamics on high iron anomaly. Hydrol J 15:495-513

Rawat KS, Tripathi VK (2015) Hydro-chemical survey and quantifying spatial variations of groundwater quality in Dwarka, subcity of Delhi, India. The Institution of Engineers (India). Springer. doi:10.1007/s40030-015-0116-0

Rawat KS, Mishra AK, Sehgal VK, Tripathi VK (2012) Spatial variability of ground water quality in Mathura district (Uttar Pradesh, India) with geostatistical method. Int J Remote Sensing Appl 2(1):1-9

Rawat KS, Mishra AK, Sehgal VK, Tripathi VK (2013) Identification of geospatial variability of fluoride contamination in ground water of Mathura District, Uttar Pradesh, India. J Appl Nat Sci 4(1):117-122
Shrestha S, Kazama F (2007) Assessment of water quality using multivariate statistical techniques: a case study of Fuji river basin, Japan. Environ Model Softw 22:464-475

Singh SK, Singh CK, Kumar KS, Gupta R, Mukherjee S (2009) Spatial-temporal monitoring of groundwater using multivariate statistical techniques in Bareilly district of Uttar Pradesh India. J Hydrol Hydromech 57(1):45-54. doi:10.2478/V10098-0090005-1

Singh SK, Srivastava PK, Gupta M, Mukherjee S (2012) Modeling mineral phase change chemistry of groundwater in a rural-urban fringe. Water Sci Tech 66(7):1502-1510. doi:10.2166/wst.2012. 338

Singh SK, Srivastava PK, Pandey AC, Gautam SK (2013a) Integrated assessment of groundwater influenced by a confluence river system: concurrence with remote sensing and geochemical modelling. Water Resour Manag 27:4291-4313

Singh SK, Srivastava PK, Pandey AC (2013b) Fluoride contamination mapping of groundwater in Northern India integrated with geochemical indicators and GIS. Water Sci Technol Water Supply 13(6):1513-1523

Singh SK, Srivastava PK, Singh D, Han D, Gautam SK, Pandey AC (2015) Modeling groundwater quality over a humid subtropical region using numerical indices, earth observation datasets, and X-ray diffraction technique: a case study of Allahabad district, India. Environ Geochem Health 37:157-180

Singh SK, Srivastava PK, Szilárd S, Petropoulos GP, Gupta M, Islam M (2016) Landscape transform and spatial metrics for mapping spatiotemporal land cover dynamics using earth observation data-sets. Geocarto Int doi:10.1080/10106049.2015.1130084

Srivastava PK, Mukherjee S, Gupta M, Singh SK (2011) Characterizing monsoonal variation on water quality index of River Mahi in India using geographical information system. Water Qual Expo Heal 2:193-203

Srivastava PK, Singh SK, Gupta M, Thakur JK, Mukherjee S (2013) Modeling impact of land use change trajectories on groundwater quality using remote sensing and GIS. Environ Eng Manag J 12:2343-2355

Thakur J, Singh P, Singh SK, Baghel B (2013) Geochemical modelling of fluoride concentration in hard rock terrain of Madhya Pradesh, India. Acta Geol Sin 87:1421-1433

Thakur JK, Diwakar J, Singh SK (2015) Hydrogeochemical evaluation of groundwater of Bhaktapur Municipality, Nepal. Environ Earth Sci 74(6):4973-4988. doi:10.1007/s12665-015-4514-4

Todd DK (1980) Groundwater hydrology. Wiley, India

Uphori DU, Toth J (1988) Patterns of ground water chemistry, Ross Crek basin, Alberta, Canada. Groundwater 27(T):20-26

World Health Organization (WHO) (1993) Guidelines for drinking water quality, vol 1-3, 2nd edn. World Health Organization, Geneva 